\title{
EVOLUTIONARY DIVERSIFICATION AND HISTORICAL BIOGEOGRAPHY OF THE ORCHIDACEAE IN CENTRAL AMERICA WITH EMPHASIS ON COSTA RICA AND PANAMA
}

\author{
Diego Bogarín ${ }^{1,2,3,7}$, Franco Pupulin $^{1}$, Erik SMets $^{3,4,5} \&$ Barbara Gravendeel $^{3,4,6}$ \\ ${ }^{1}$ Lankester Botanical Garden, University of Costa Rica, Cartago, Costa Rica \\ ${ }^{2}$ Herbarium UCH, Autonomous University of Chiriquí, Chiriquí, Panama \\ ${ }^{3}$ Naturalis Biodiversity Center, Leiden University, Leiden, The Netherlands \\ ${ }^{4}$ Institute Biology Leiden, Leiden University, Leiden, The Netherlands \\ ${ }^{5}$ KU Leuven, Ecology, Evolution and Biodiversity Conservation, Leuven, Belgium \\ ${ }^{6}$ University of Applied Sciences Leiden, Leiden, The Netherlands \\ ${ }^{7}$ Author for correspondence: diego.bogarin@ucr.ac.cr
}

\begin{abstract}
Historically, the isthmus of Costa Rica and Panama has been a source of fascination for its strategic position linking North America to South America. In terms of biodiversity, the isthmus is considered one of the richest regions in the world. Orchidaceae is the most diverse plant family in the area, and the number of species is triple that of other well-represented angiosperm families such as Rubiaceae, Fabaceae and Poaceae. Though we are still far from knowing the exact number of orchid species occurring extant in both countries nowadays, at present the orchid flora reported for Costa Rica (1574 spp.) and Panama (1372 spp.) summarise together about 2010 species; which represents $6.5-8.0 \%$ of all orchid species on just about $1 \%$ of the Earth's land surface. Pleurothallidinae and Laeliinae are the most species rich groups and contain the largest genera: Lepanthes, Pleurothallis, Stelis and Epidendrum. These groups significantly outnumber the other genera recorded in terms of species richness. Some factors explaining this regional taxonomic diversity of orchids are the natural land bridge uniting three of the 25 recognized hotspots worldwide (Mesoamerica, Choco/Darien/Western Ecuador and tropical Andes), the climatic influence of the Pacific and Atlantic oceans, and the recent lifting of the Cordillera de Talamanca and the formation of foothills of Majé, Darien and San Blas in Panama and western Colombia. Although these factors can explain the high diversity in general terms, detailed information is needed to understand species diversification as well as the evolution of the floristic composition. Updated floristic inventories (yielding a rate of 25 new species/year) and the study of biological mechanisms that have led to the evolutionary diversification of Lepanthes (one of the major groups of orchids) are the main ongoing research projects to elucidate the evolution of Orchidaceae in Costa Rica and Panama. Towards this end, we present some preliminary results of the research conducted in this direction including the integration of phylogenetics, pollination ecology, taxonomy and biogeography.
\end{abstract}

Resumen: Históricamente, el Istmo de Costa Rica y Panamá ha sido fuente de fascinación por su posición estratégica, uniendo América del Norte con América del Sur. En términos de biodiversidad, el Istmo es considerado una de las regiones más ricas del mundo. Orchidaceae es la familia de plantas más diversa en la zona, y el número de especies triplica a otras familias de angiospermas bien representadas como Rubiaceae, Fabaceae y Poaceae. Aunque todavía estamos lejos de conocer el número exacto de especies de orquídeas existentes en ambos países, en la actualidad la flora de orquídeas registradas para Costa Rica (1574 spp.) y Panamá (1372 spp.) suman en conjunto alrededor de 2010 especies; lo que representa 6,5-8,0\% de todas las especies de orquídeas en apenas alrededor de $1 \%$ de la superficie terrestre del planeta. Pleurothallidinae y Laeliinae son los grupos más ricos en especies y contienen la mayor géneros: Lepanthes, Pleurothallis, Stelis y 
Epidendrum. Estos grupos superan significativamente los otros géneros registrados en términos de riqueza de especies. Algunos de los factores que explican esta diversidad taxonómica regional de orquídeas son el puente natural que une tres de los 25 puntos reconocidos en todo el mundo (Mesoamérica, Chocó / Darién / Ecuador Occidental y Andes tropicales), la influencia climática de los océanos Pacífico y Atlántico, y la reciente elevación de la Cordillera de Talamanca y la formación de estribaciones de Majé, Darién y San Blas, en Panamá y el oeste de Colombia. Aunque estos factores pueden explicar la alta diversidad de orquídeas en términos generales, se necesita información detallada para comprender la diversificación de especies, así como la evolución de la composición florística. Los inventarios florísticos actualizados (con una tasa de 25 nuevas especies / año) y el estudio de los mecanismos biológicos que han llevado a la diversificación evolutiva de Lepanthes (como uno de los géneros más grandes de orquídeas) son los principales proyectos de investigación en curso para dilucidar la evolución de Orchidaceae en Costa Rica y Panamá. Con este fin, presentamos algunos resultados preliminares de la investigación llevada a cabo en esta dirección que incluye la integración de estudios filogenéticos, ecología de la polinización, taxonomía y biogeografía.

KeY WORDS / PALABRAS CLAVE: biodiversity, floristics, pollination ecology, Lepanthes / biodiversidad, florística, la polinización ecología, Lepanthes

Introduction. Historically, the isthmus of Costa Rica and Panama has been a source of fascination for its strategic position linking North America to South America. The geological events that led to the closure of the isthmus that started with the formation of a volcanic arc dating fromlatest Cretaceous to Eocene, 67 to 39 million years ago (Mya) (Montes et al. 2015) have been studied extensively but are still controversial. There is no consensus about when the isthmus closed completely the Central American Seaway (CAS) separating the Pacific from the Atlantic Ocean and favoring the Great American Biotic Interchange (GABI). Traditionally this time, however, was established between 3.5-5.0 Mya, but other studies that include new information suggest a closure between 13-15 Mya in the middle Miocene (Bacon et al. 2015, Montes et al. 2015). Despite this, with the initial emergence of a volcanic arc in the Cretaceous, orchids had time to colonize some of these oceanic islands by wind dispersal of seeds and evolve there.

According to a phylogenomic analysis and net diversification regimes across lineages using BAMM analysis, Givnish et al. (2015) proposed that Orchidaceae arose around 112 Mya in the Cretaceous, long before the formation of the arc and subsequent closure of the Isthmus of Panama. However, the

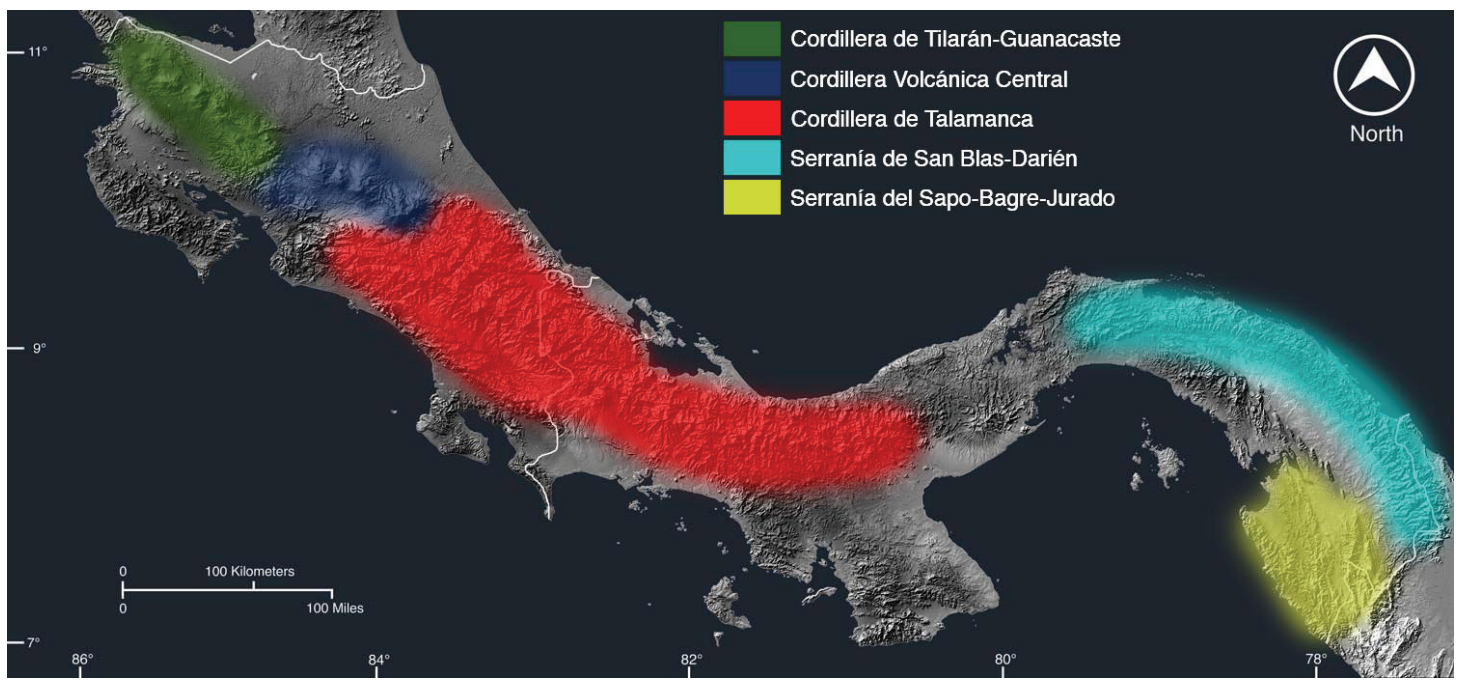

Figure 1. Geography of southern Central America (Costa Rica and Panama) showing the main ranges: Talamanca crossing both countries and San Blas-Darien on the southeast of Panama towards Colombia. 
most diverse Neotropical subtribes: Laeliinae, Oncidiinae, Maxillariinae and Pleurothallidinae probably diversified between 10-25 Mya after the last acceleration of net diversification rate that occurred about 25 Mya, overlapping with the possible closure of the Isthmus proposed recently (Bacon et al. 2015, Givnish et al. 2015, Montes et al. 2015). Indeed the flora of the Isthmus is dominated mainly by species of Laeliinae and Pleurothallidinae that diversified about $18 \mathrm{Mya}$. Analyzing the current floristic composition of the species in Costa Rica and Panama (Fig. 1) we could find general patterns that help to understand better the evolutionary and biogeographic relationships among other geologically older regions such as the Andes, northern Central America and the Antilles.
TABLE 1. Number of genera, species and endemics (\%) in Costa Rica and Panama.

\begin{tabular}{l|c|c|c}
\hline & Costa Rica & Panama & Total \\
\hline Genera & 199 & 187 & 211 \\
\hline Species & 1574 & 1372 & 2012 \\
\hline Endemics & $485(30.8)$ & $299(21.8)$ & 784 \\
\hline
\end{tabular}

Orchidaceae diversity in Costa Rica and Panama. Updated floristic inventories in Costa Rica and Panama (both countries treated as a biogeographic unit) contain some 2012 species of orchids of which 934 are shared (Bogarín et al. 2014b, Bogarín in prep.). From these figures, 784 (39\%) species are endemic to the Isthmus (Table 1).

A strategy to analyze the current evolutionary and

Table 2. The most diverse genera in Costa Rica and Panama. Number of species and percentage relative to the total of species of each genus.

\begin{tabular}{l|c|l|c}
\hline Costa Rica & Number of species (\%) & Genus & Number of species (\%) \\
\hline Genus & $207(13.8)$ & Epidendrum & $221(14.7)$ \\
\hline Epidendrum & $88(11.0)$ & Lepanthes & $151(13.5)$ \\
\hline Stelis & $66(5.9)$ & Stelis & $103(12.9)$ \\
\hline Lepanthes & $54(6.8)$ & Camaridium & $48(32.0)$ \\
\hline Pleurothallis & $48(32.0)$ & Pleurothallis & $48(6.0)$ \\
\hline Camaridium & $39(35.5)$ & Specklinia & $44(44.0)$ \\
\hline Scaphyglottis & $39(17.7)$ & Scaphyglottis & $38(34.5)$ \\
\hline Sobralia & $34(34.0)$ & Sobralia & $38(17.3)$ \\
\hline Specklinia & $32(8.0)$ & Telipogon & $37(14.8)$ \\
\hline Oncidium & $26(26.0)$ & Masdevallia & $34(3.8)$
\end{tabular}

TABLE 3. Percentage of the number of endemic species and the total of species of the genera with most endemic species in Costa Rica and Panama

\begin{tabular}{l|c|l|c}
\hline \multicolumn{2}{l|}{ Costa Rica } & Panama & Endemic species (\%) \\
\hline Genus & Endemic species (\%) & Genus & 73.9 \\
\hline Telipogon & 83.8 & Telipogon & 42.6 \\
\hline Lepanthes & 67.5 & Pleurothallis & 42.6 \\
\hline Sobralia & 39.5 & Sobralia & 34.6 \\
\hline Masdevallia & 38.2 & Masdevallia & 31.5 \\
\hline Epidendrum & 36.2 & Lepanthes & 33.3 \\
\hline Stelis & 35.9 & Stelis & 23.1 \\
\hline Specklinia & 31.8 & Epidendrum & 16.7 \\
\hline Pleurothallis & 31.3 & Camaridium & 20.6 \\
\hline Camaridium & 29.2 & Specklinia & \\
\hline
\end{tabular}



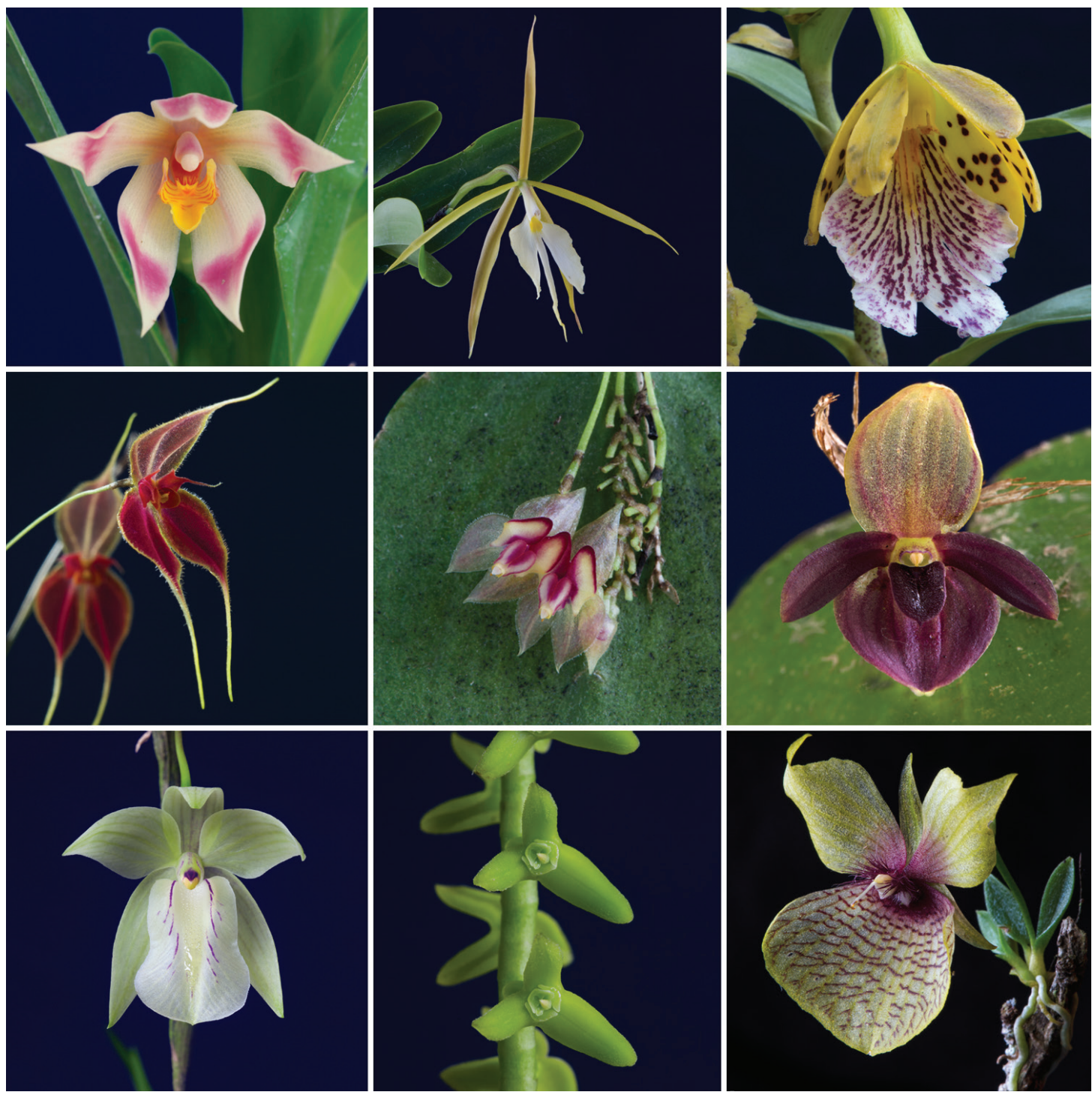

FIGURE 2. Some representatives of the major groups of Orchidaceae present in Costa Rica and Panama. From left to right: Camaridium campanulatum, Epidendrum nocturnum, Epidendrum (Oerstedella) wallisii, Lepanthes matamorosii, L. bradei, Pleurothallis sp., Scaphyglottis pulchella, Stelis transversalis, Telipogon panamensis.

floristic relationships of the Orchidaceae of the Isthmus is the study of the most diverse groups in the region. An analysis of the various genera occurring in both Costa Rica and Panama shows that Epidendrum L., Lepanthes Sw. and Stelis s.s. Sw. contain the most species and the highest rates of endemism (Tables 2,3). These genera are also monophyletic (Pridgeon et al. 2001) and therefore there is no bias due to the use of different nomenclatural circunscriptions that might cause variations in the number of species assigned to a genus.
One factor that can affect the interpretation of evolutionary and biogeographic data is the intensity of the alpha-taxonomic work. The most diverse genus in the Isthmus is Epidendrum, the taxonomy of which has been developed in detail and consistently by Hágsater and colleagues. Lepanthes is a diverse genus, and despite extensive work by Luer (2003a) there are still many species to be revealed, especially in the Cordillera de Talamanca and Panama. If this trend continues, Lepanthes may exceed Epidendrum in 
number of species recorded in the Isthmus (Pupulin \& Bogarín, 2014). Moreover, the taxonomy of Stelis s.s. is the least developed, and the conclusions based on these data are likely biased (Luer, 2003b). Botanical exploration and alpha-taxonomy are therefore tasks that must be promoted with impetus in the region.

Some other diverse groups in the Isthmus are Camaridium Lindl., Dichaea Lindl., Oncidium Sw., Pleurothallis R.Br., Scaphyglottis Poepp. \& Endl., Sobralia Ruiz \& Pav., Specklinia Lindl. and Telipogon Kunth. (Fig. 2) These groups also maintain a tendency to hold many endemic species. The taxonomic work in these genera has also revealed new species and expanded geographic distributions, encouraging more potential case studies to understand the evolution and diversification of Orchidaceae in the Isthmus (Pupulin et al. 2012, Bogarín et al. 2014a, Dressler \& Pupulin 2015).

\section{Biogeography and endemism in Costa Rica and}

Panama. About $40 \%$ of the species are endemic to the Isthmus. The highest rate of endemism recorded could be related to geological events of volcanic arc and vicariance phenomena produced by the lifting of the Cordillera de Talamanca. Allopatric speciation in Lycaste bruncana Bogarín and L. tricolor Rchb.f. (Fig. 3) - among other examples also found in Brassia R.Br., Epidendrum, Kefersteinia Rchb.f., Oncidium, Pleurothallis and Stelis - indicate an important role of the altitudinal division produced by Talamanca and its climate barrier effect blocking the Caribbean tradewinds (Pupulin 2001, Bogarín 2007, Pupulin \& Bogarín 2012).

The highest rates of endemism are found in the most diverse genera. For example, $90 \%$ of the species of Lepanthes are endemic and about $50 \%$ of the species of Stelis and Epidendrum (Table 4). The study of the factors favoring this high endemism in Lepanthes is key to understanding its diversification and will be discussed later as a study model group. Other genera attract attention because, although not as diverse, they show high rates of endemism; one of these is Telipogon, in which more than $70 \%$ of species are endemic. Current floristic relationships with other groups of orchids of the Andes is evident. Telipogon is a diverse genus in the highlands of the Isthmus, and its northern distribution is limited
TABLE 4. The most diverse genera and the $\%$ of endemic species in Costa Rica and Panama

\begin{tabular}{l|c|c}
\hline & $\begin{array}{c}\text { Species } \\
\text { in the Isthmus }\end{array}$ & $\begin{array}{c}\% \\
\text { endemic species }\end{array}$ \\
\hline Lepanthes & 155 & 90.12 \\
\hline Epidendrum & 133 & 46.18 \\
\hline Stelis & 60 & 43.80 \\
\hline
\end{tabular}

(Williams, Whitten, \& Dressler, 2005). Other genera of South American affinities are Brachionidium Lindl., Fernandezia Lindl. and Pterichis Lindl. that almost reach their northernmost distribution in the Cordillera de Talamanca (Bogarín et al. 2014b).

About 10 genera are present in Panama but not in Costa Rica. These genera have a strong South American relationship: Discyphus Schltr., Eloyella P.Ortiz, Koellensteinia Rchb.f., Neomoorea Rolfe, Rudolfiella Hoehne and Selenipedium Rchb.f. They range from Central Panama to the southeast of Darien and towards Colombia, indicating a common geological history of this area but different from western Panama and southeast Costa Rica. The geological formation of foothills of Maje, Darien and San Blas in Panama and western Colombia is reflected in our species composition data. Because of its [antecedent? To what does this refer?] geographical distribution, it is likely that species in Dinema Lindl., Euryblema Dressler, Helleriella A.D. Hawkes and Horichia Jenny can be recorded with high probability in Costa Rica (Bogarín et al. 2014b).

On the other hand 18 genera are present in Costa Rica and are still not registered in Panama. Some of them have mostly a northern influence such as Arpophyllum La Llave \& Lex. and Restrepiella Garay \& Dunst. However, it is likely that Epistephium Kunth, Funkiella Schltr., Lankesterella Ames, Trevoria F.Lehm., Tropidia Lindl. and Warmingia Rchb.f. with representatives in South America are distributed in Panama. The bias resulting from less floristic and alpha-taxonomic work in Panama should be reduced in the upcoming years (Bogarín et al. 2013).

\section{Evolutionary diversification and floristic composition of Costa Rica and Panama. Our focus} is on studying the factors that led to the formation of the current species composition of Orchidaceae in the Isthmus. Based on our taxonomic experience we 


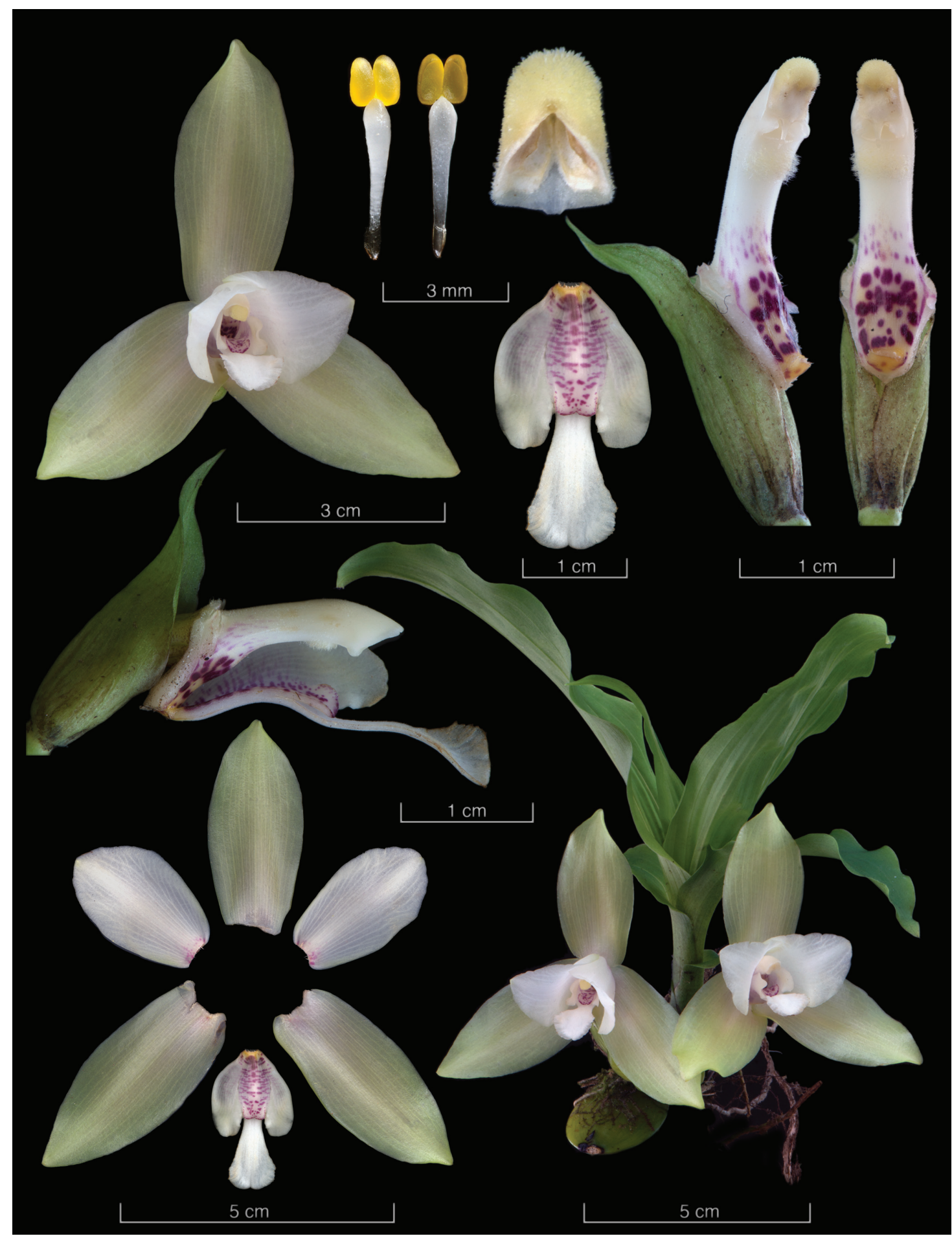

FiguRE 3. Lankester Composite Digital Plate of Lycaste bruncana, a species from Costa Rica and Panama restricted to the Pacific watershed of Cordillera de Talamanca. 

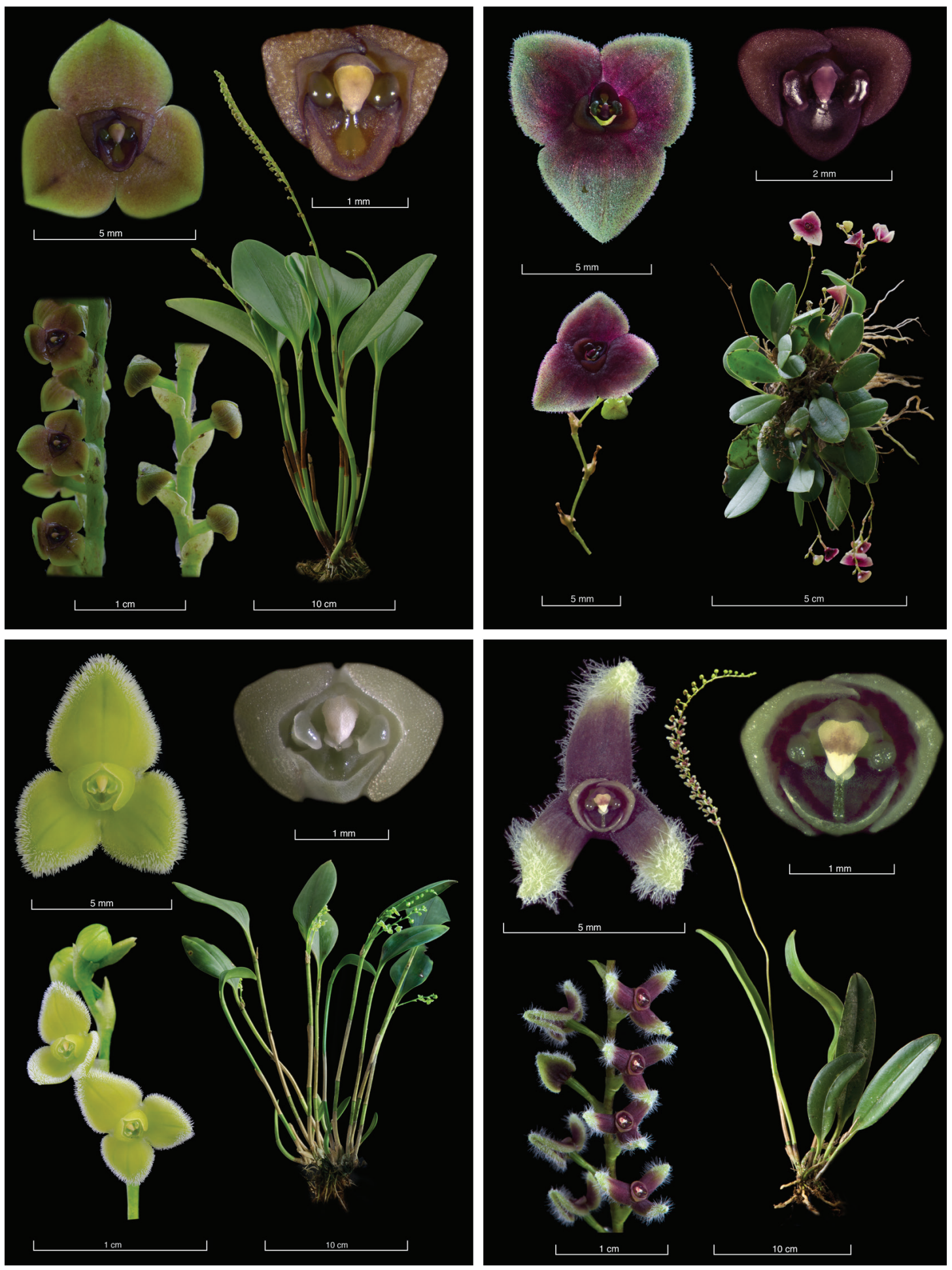

FIgURE 4. Some species of the highly diverse genus Stelis from Costa Rica and Panama. Species are currently under taxonomic review. 


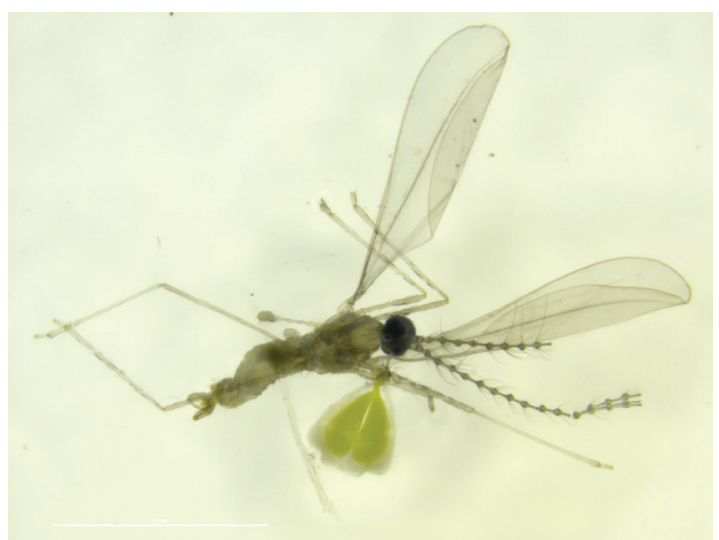

FIGURE 5. Species of Cecydomiididae carring a pollinarium of Stelis cf. parvula.

have selected Lepanthes and closely related genera as a model group to study the extraordinary species richness and evolution in Costa Rica and Panama and its relationship with the Andean flora. We intend in the future to extend this model to other diverse groups such as Stelis. Epidendrum is another interesting group, and it is being evaluated by Hágsater and coworkers so there will be information available in the future. Although Stelis s.s. remains an excellent group as a candidate to study their high evolutionary diversification, the limited taxonomic expertise and little ecological information prevents us to address this group (Fig. 4). However, some clues about its pollination mechanism (hitherto little-known) indicate that it may be pollinated by gall midges of Cecidomyiididae under conditions that we are still exploring (Fig. 5).

The genus Lepanthes. Lepanthes is one of the major genera in the Pleurothallidinae. With over 1000 spp., the genus ranges from southern Mexico and the Antilles to Peru and Bolivia, with few species in the Guianas and Brazil. Plants grow mostly from 1500 to $3000 \mathrm{~m}$ elevation in humid, often shady places. Highest diversity is found in the Andean region of Colombia and Ecuador with more than 300 species in each country (Luer 1996, Luer \& Thoerle 2012) (Fig. 6). Lepanthes is represented in Costa Rica and Panama with about 150 spp. Only two species are shared with Colombia and Ecuador. This may reflect the floristic influence of the Andean region in Costa Rica and Panama at the genus level but not the species level. Species are usually restricted to specific ranges or mountains, and endemism is high.

Plants are recognized by the monophyllous ramicauls, enclosed by a series of lepanthiform sheaths and congested, distichous inflorescences. Floral morphology distinguishes Lepanthes from other genera with lepanthiform sheaths (Draconanthes (Luer) Luer, Trichosalpinx Luer and Lepanthopsis (Cogn.) Hoehne among others). Flowers are characterized by the ovate to elliptic sepals and the transversely bilobed petals. Lip morphology is complex (Fig. 7). It is usually bilaminate with the two blades supported by connectives that often lift the blades above the column. The central part of the lip is made up by the body, which is attached to the column. The appendix is developed from the sinuous between the connectives andvaries morphologically among the species in different combinations of lobes, hairs, projections, trichomes and membranes. Although Lepanthes has been poorly sampled phylogenetically, it is considered a monophyletic group (Pridgeon, Solano-Gómez \& Chase, 2001). Our preliminary phylogenetic analysis support the monophyly of Lepanthes. It is important to note that the genus Neooreophilus Archila, which is closely related to Andinia (Luer) Luer and not to Lepanthes, seems to be a case of convergence (Fig. 8). Neooreophilus species have a similar flower morphology as Lepanthes, and there is some evidence of its pollination by pseudocopulation (S. VieiraUribe, pers. comm. 2015). Neooreophilus is absent in Mesoamerica, and it might be a younger group when compared to Lepanthes, which is widespread in the Neotropics. Phylogenetics of these two groups will help to shed light on this hypothesis.

The floral morphology of Lepanthes varies astonishingly around the same scheme in all the $>1000$ species known. Petals and lip tend to be reduced or almost absent in some species. Flowers are developed above or beneath the leaves or sometimes in inflorescences surpassing the leaves. The most common colors of flowers are yellow, red, orange, purple (rarely green) or a combination of these. The appendix plays an important role in pollination of Lepanthes flowers. Blanco \& Barboza (2005) described the first case of pseudocopulation in the genus. Males of a fungus gnat, Bradysia floribunda (Diptera: Sciaridae), visit flowers of L. glicensteinii Luer, apparently attracted by sexual 


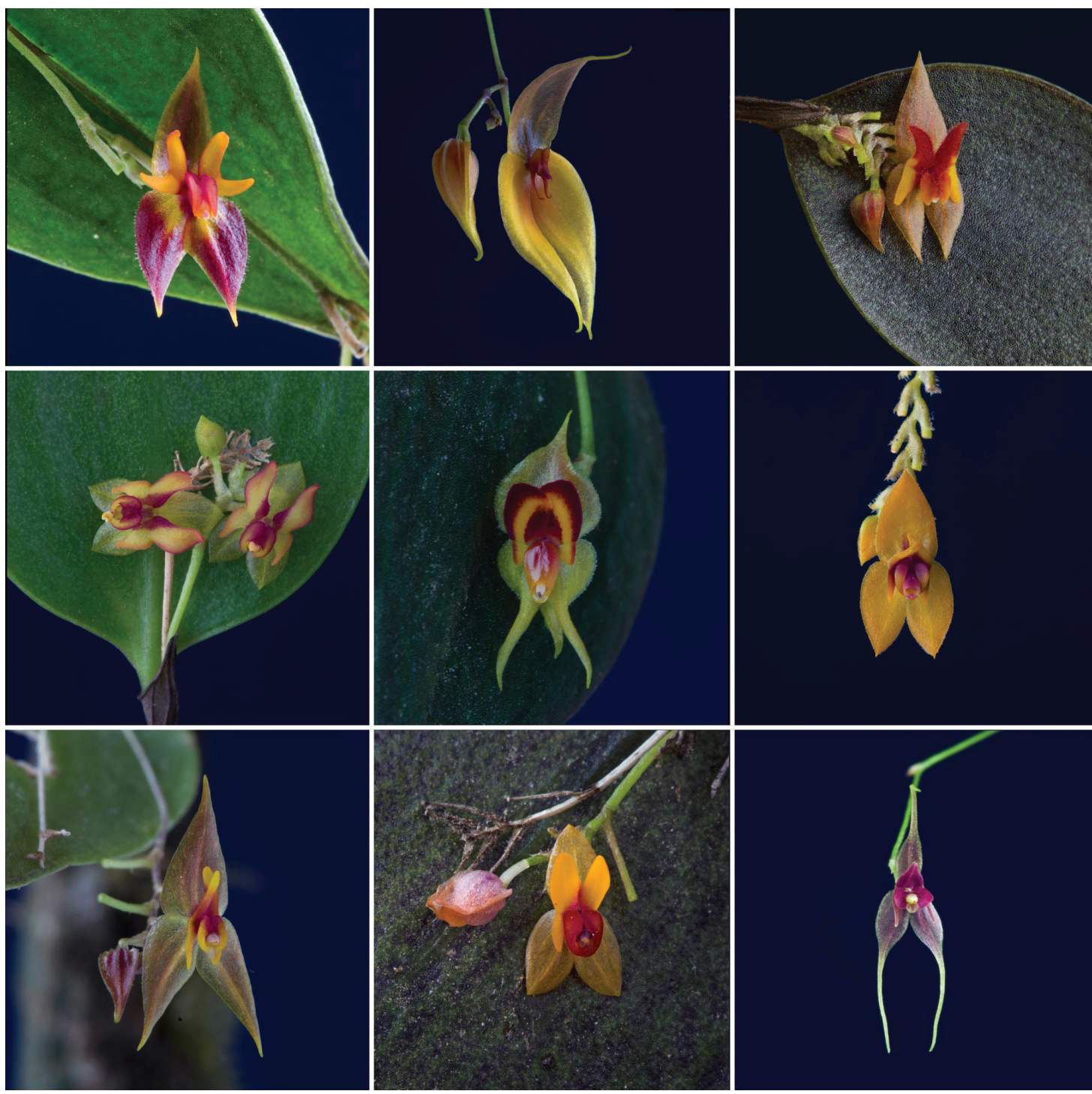

FIgURE 6. Some species of Lepanthes from Costa Rica and Panama. Species are mostly endemic and show a wide range of morphological variation around the same scheme. Note the coloration of the flowers, which might be involved in attraction of pollinators.

pheromone-like scents. The male adheres to the flower appendix during its attempt copulation. In this process the insect removes the pollinarium with the abdomen. Calderon-Sáenz (2012) observed the same phenomenon in L. yubarta E.Calderon visited by a species of Bradysia in Valle del Cauca, Colombia. Sciaridae flies, commonly known as dark-winged fungus gnats, are a diverse group of insects with more than 8000 species worldwide. Eggs are deposited between the lamina of sporocarps of fungi, and the larvae feed on sporocarps and other decaying organic matter such as rotten trunks or plant roots or leaves. Some species are pests of important economic crops such as mushrooms. Blanco \& Barboza (2005) and Calderon-Sáenz (2012) clearly described the pollination of Lepanthes but left many evolutionary questions unanswered. We are studying more cases of pollination in other Lepanthes species where morphological evidence indicates that other parts of the body of insects are being used such that the pollinia are not always attached to the abdomen. It is 


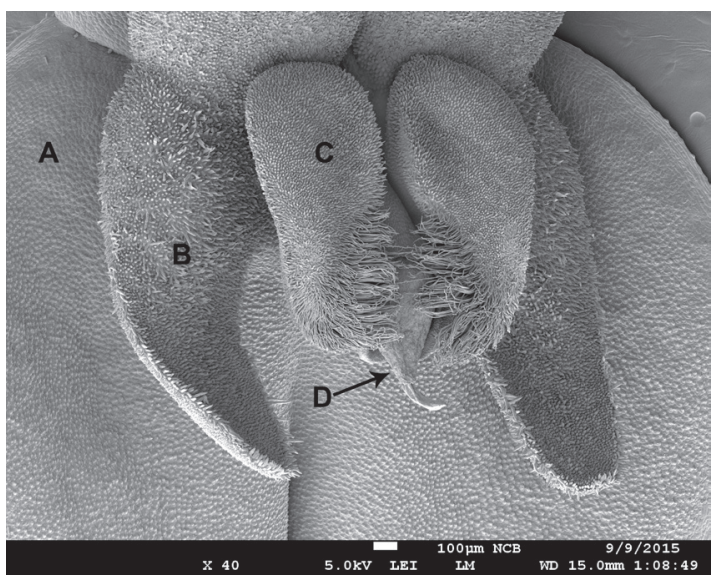

FIGURE 7. Scanning electron microscopy (SEM) of a flower of Lepanthes horichii showing the complex morphology in detail. A. Sepal., B. Petal (lower lobe)., C. Lip (lobe)., D. Column showing the apical anther.

likely that production of pheromone-like compounds are the sources of attraction. We have evidence that flowers use this strategy to attract males. The anatomy of the flower is being studied in order to find possible secretory structures involved in pollinator attraction (Fig. 7).

Sciarids are attracted by yellow colors. Special traps are designed to catch flies in greenhouses made up by yellow cardboard and petroleum jelly. Although this method proved to be less effective in studying Lepanthes pollination (Godden 2002), the approach needs to be used in large populations to increase the probabilities of catching flies with pollinia.

Sciarid flies have short life cycles (Wilkinson \& Daugherty, 1970). Adults usually live less than 7 days, and they are considered poor flyers. Thus the chance to deceive the inexperienced males may be high. Sciaridae is a highly diverse group but poorly known. Indeed, the pollinator of $L$. glicensteinii observed by Blanco \& Barboza (2005) was an undescribed species. The behavior and natural history of Sciaridae are key to understanding the evolution of Lepanthes.

Why is Lepanthes more diverse than closely related genera such as Anathallis Barb.Rodr., Draconanthes, Lankesteriana Karremans, Lepanthopsis, Trichosalpinx and Zootrophion Luer? A hypothesis is that pseudocopulation triggered the high speciation levels in Lepanthes. To study the evolutionary diversification of Lepanthes and the possible triggers of speciation, it will be necessary to extend the molecular phylogenetic sampling of the "Lepanthes- clade" as described by Pridgeon, Solano-Gómez \& Chase (2001) in order to find answers to the evolutionary success of Lepanthes as compared to its sister genera. However, the pollination mechanisms that operate in those sister genera are also important for comparisons with Lepanthes. Preliminary observations on the pollination of Trichosalpinx revealed a frequent visitation by biting midges of the Ceratopogonidae family. The taxonomy of Trichosalpinx has been treated by Luer (2003c) and more recently by Fernández (2013), and systematic studies of Lepanthopsis, Anathallis, Lankesteriana and Zootrophion are underway. Lepanthes taxonomy has been studied by Luer \& Thoerle (2012) and particularly in Costa Rica and Panama by Luer \& Dressler (1986), Luer (2003a), Pupulin, Bogarín \& Jiménez (2009) and Pupulin \& Bogarín (2014).

Givnish et al. (2015) pointed out that all factors such as the role of limited dispersal of seeds and ineffective pollinators, limited gene flow, population
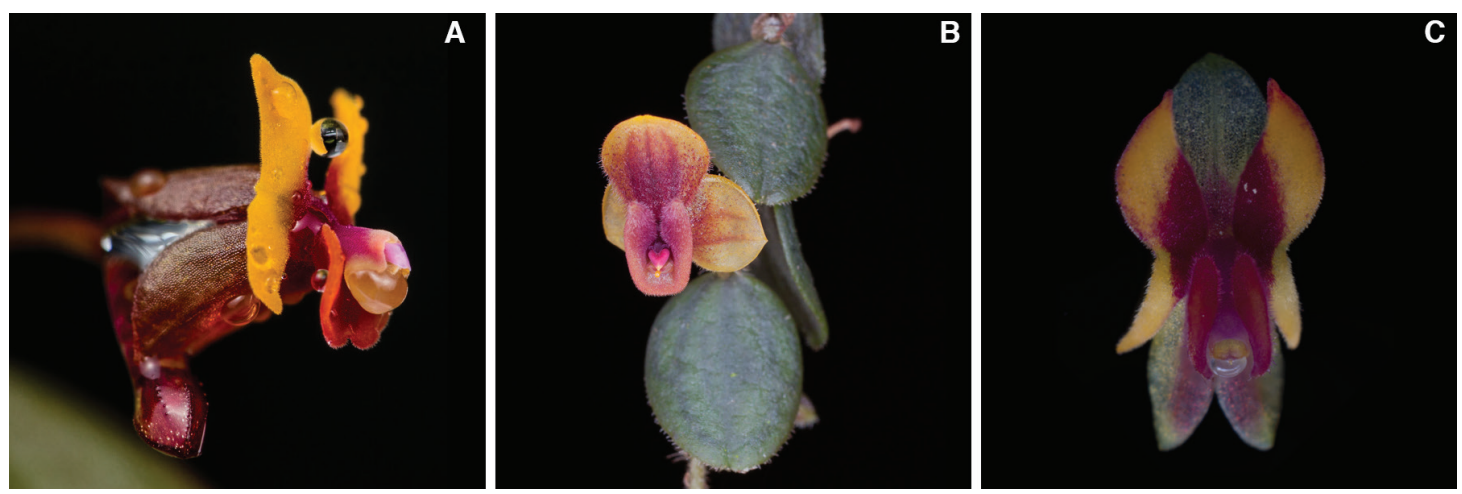

Figure 8. Floral convergence among the species of Neooreophilus (A, B) and Lepanthes (C). 
bottlenecks and genetic driftdeserve to be studied, and Lepanthes is one of the best study cases for that. We also propose the delimitation of biogeographical areas within Costa Rica and Panama in order to draw accurate conclusions about endemism and species distribution. It would be advisable that some of the topics discussed here include the Andean flora, which is particularly rich in these groups of orchids. This study has future conservation applications because the major groups of orchids and associated pollinators and hosts are vulnerable to climate change in cold, highelevation areas where they are most diverse.

ACKNOWLEDGMENTS. We acknowledge the staff of Lankester Botanical Garden University of Costa Rica and the Naturalis Biodiversity Center. The Vice-Presidency of Research of the University of Costa Rica provided support through the project "Filogenia, diversificación evolutiva y biogeografía histórica de los principales grupos de orquídeas en la Baja Centroamérica (Costa Rica y Panamá) con énfasis en Lepanthes y géneros cercanos (Pleurothallidinae)" (814-B6-140). We thank the Costa Rican Ministry of Environment and Energy (MINAE) and its National System of Conservation Areas (SINAC) for issuing the Scientific Passports under which wild species treated in this study were collected. The organizers of the Fifth Scientific Conference on Andean Orchids for the provided facilities for the event. Jerry Harrison and two anonymous reviewers made helpful comments on the manuscript. This work is part of the Ph.D. project of the first author, titled "Evolutionary diversification and historical biogeography of the Orchidaceae in Central America with emphasis on Costa Rica and Panama," at the University of Leiden, The Netherlands and Naturalis Biodiversity Center.

\section{LiTERATURE CITED}

Bacon, C. D., Silvestro, D., Jaramillo, C., Smith, B.T., Chakrabarty, P. \& Antonelli, A. (2015). Biological evidence supports an early and complex emergence of the Isthmus of Panama. Proceedings of the National Academy of Sciences, 112, 6110-6115.

Bogarín, D. (2007). A new Lycaste (Orchidaceae: Maxillariinae) from Costa Rica. Lankesteriana 7(3) : 543-549.

Bogarín, D., Pupulin, F., Arrocha, C. \& Warner, J. (2013). Orchids without borders: studying the hotspot of Costa Rica and Panama. Lankesteriana 13(1-2): 13-26.

Bogarín, D., Serracín, Z. \& Samudio, Z. (2014a). Illustrations and studies in Neotropical Orchidaceae. The Specklinia condylata group (Orchidaceae) in Costa Rica and Panama. Lankesteriana 13(3): 185-206.
Bogarín, D., Serracín, Z., Samudio, Z., Rincón, R. \& Pupulin, F. (2014b). An updated checklist of the Orchidaceae of Panama. Lankesteriana 14(3): 135-364.

Blanco, M.A. \& Barboza, G. (2005). Pseudocopulatory pollination in Lepanthes (Orchidaceae: Pleurothallidinae) by fungus gnats. Annals of Botany 95: 763-772.

Calderón-Sáenz, E. (2012). Remoción de polinarios de Lepanthes yubarta por una mosca fungosa del género Bradysia, bajo condiciones seminaturales. Orquideología XXIX(1): 31--34.

Godden, G.T. (2002). Pollination and speciation of Lepanthes: an approach to understanding orchid evolution. Pleurothallid News and Views 14: 52-54.

Dressler, R.L. \& Pupulin, F. (2015). Sobralia lentiginosa (Orchidaceae: Sobralieae). An attractive new species from Costa Rica. Lindleyana in Orchids (Bull. Amer. Orch. Soc.) 84(6): 374-376.

Fernández, M. (2013). Tubella - die etwas anderen Trichosalpinx. Tubella: Those other Trichosalpinx. Die Orchidee 64(4): 310-317

Givnish, T. J, Spalink, D., Ames, M., Lyon, S.P., Hunter, S.J., Zuluaga, A., Iles, W. J., Clements, M. A., Arroyo, M.T., Leebens-Mack, J., Endara, L., Kriebel, R., Neubig, K.M., Whitten, W.M., Williams, N.H., Cameron, K.M. (2015). Orchid phylogenomics and multiple drivers of their extraordinary diversification. Proceedings of the Royal Society B: Biological Sciences 282(1814). doi: 10.1098/rspb.2015.1553.

Luer, C.A. (1996). Icones Pleurothallidinarum, XIV: The genus Lepanthes, subgenus Lepanthes in Ecuador. Monographs in Systematic Botany from the Missouri Botanical Garden 61: 1-255.

Luer, C.A. (2003a). Lepanthes. In: B. E. Hammel, M.H. Grayum, C. Herrera \& N. Zamora (Eds.), Manual de Plantas de Costa Rica Vol. 3. (pp. 216-255) Monocotiledóneas (Orchidaceae-Zingiberaceae). Monographs in Systematic Botany from the Missouri Botanical Garden 93: 1-884.

Luer, C.A. (2003b). Stelis. In: B. E. Hammel, M.H. Grayum, C. Herrera \& N. Zamora (Eds.), Manual de Plantas de Costa Rica Vol. 3. (pp. 521-245) Monocotiledóneas (Orchidaceae-Zingiberaceae). Monographs in Systematic Botany from the Missouri Botanical Garden 93: $1-884$.

Luer, C.A. (2003c). Trichosalpinx. In: B. E. Hammel, M.H. Grayum, C. Herrera \& N. Zamora (Eds.), Manual de Plantas de Costa Rica Vol. 3. (pp. 569578) Monocotiledóneas (Orchidaceae-Zingiberaceae). Monographs in Systematic Botany from the Missouri Botanical Garden 93: 1-884.

Luer, C.A. \& Thoerle, L. (2012). Icones Pleurothallidinarum XXXII: Lepanthes of Colombia. Monographs in 
Systematic Botany from the Missouri Botanical Garden 123: 1-300.

Montes, C., Cardona, A., Jaramillo, C., Pardo, A., Silva, J.C., Valencia, V., Ayala, C., Pérez-Angel, L.C., Rodríguez-Parra, L.A., Ramírez, V., Niño, H. (2015). Middle Miocene closure of the Central American Seaway. Science 348(6231): 226-229.

Pridgeon, A.M., Solano-Gómez, R. \& Chase, M.W. (2001). Phylogenetic relationships in Pleurothallidinae (Orchidaceae): combined evidence from nuclear and plastid DNA sequences. American Journal of Botany 88: 2286-2308. http://dx.doi.org/10.2307/3558390

Pupulin, F. (2001). Contributions to a reassessment of Costa Rican Zygopetalinae (Orchidaceae). The genus Kefersteinia Rchb.f. Annalen des Naturhistorisches Museums Wien 103B: 525-555.

Pupulin, F. \& Bogarín, D. (2012). A new Oncidium from Costa Rica. Lindleyana in Orchids (West Palm Beach) 81(3): 176-179.
Pupulin, F. \& Bogarín, D. (2014). Aliae Lepanthes Machogaffenses (Orchidaceae: Pleurothallidinae). Harvard Papers in Botany 19(2): 194-201.

Pupulin, F., Bogarín, D \& Jiménez, D. (2009). New species and records in Mesoamerican Lepanthes. Orchid Digest 73: 136-145.

Pupulin, F., Karremans, A.P. \& Gravendeel, B. (2012). A reconsideration of the empusellous species of Specklinia (Orchidaceae: Pleurothallidinae) in Costa Rica. Phytotaxa 63: 1-20.

Wilkinson, J.D. \& Daugherty, D.M. (1970). The biology and immature stages of Bradysia impatiens (Diptera: Sciaridae). Annals of the Entomological Society of America 63(3):656-660.

Wilson, M. \& Jost, L. (2011). Phylogenetic analysis of the Andean genus Brachycladium Luer (syn. Oreophilus Higgins \& Archila) and closely related genera based on nuclear ITS sequencing. Lankesteriana 11(3): 370. 